\title{
Editorial - n.71 v.34 - maio/ago. 2020
}

\section{Vanessa Matos dos Santos*}

Com muito orgulho, apresentamos esta nova edição, de número 71, da Revista Educação e Filosofia. Publicada em meio a um cenário marcado pelas instabilidades (sanitária, política, econômica etc), esta edição, composta por 5 artigos que abordam o tema específico do dossiê Fenomenologia e mais 11 artigos nas áreas de Educação e de Filosofia, se coloca como voz de resistência em um contexto pandêmico que alterou (e segue alterando) não apenas as estruturas da sociedade, mas sobretudo a dimensão dos nossos afetos, nossas formas de sentir e interagir com o Outro e conosco mesmo enquanto seres no mundo e não apenas do mundo.

Apesar dos tempos duros e sombrios, insistimos, seguimos, lutamos. Neste sentido, a temática deste dossiê é um convite à reflexão a partir de nós mesmos, nossas vivências cotidianas, relações e contradições. Partindo dessa premissa e do entrecruzamento da fenomenologia com o método de história de vida, o professor Paulo Roberto Brancatti e a professora Renata Portella Rinaldi apresentam, no artigo que abre este dossiê - "A fenomenologia e a história de vida" -, as contribuições dessa amálgama para o processo educacional e suas nuances pelas ciências de forma dialética com as contradições do sujeito em relação a sua formação acadêmica. Na sequência, o professor Márcio Danelon problematiza, no artigo "O movimento escola sem partido e a captura da docência: o professor como técnico do saber especializado", a atuação do professor no contexto daquele movimento. Rompendo com a lógica que busca reduzir a educação à adequação ou à revolta contra a sociedade industrial, a professora Constança Terezinha Marcondes César apresenta, no artigo

\footnotetext{
* Doutora em Educação Escolar pela Universidade Estadual Paulista Júlio de Mesquita Filho (UNESP) e em Meios e Processos Audiovisuais pela Universidade de São Paulo (USP). Professora na Faculdade de Educação da Universidade Federal de Uberlândia(UFU). E-mail: vanmatos.santos@gmail.com. ORCID: https://orcid.org/00000003-1041-367X. Membro do Comitê Editorial Executivo de Educação e Filosofia.
} 
intitulado "Fenomenologia e Educação na perspectiva de Creusa Capalbo", as contribuições de Creusa Capalbo para pensar a educação como propiciadora de valores que assegurem a realização do bem comum, para além de uma perspectiva utilitarista da educação. Deslocando a discussão para a infância sem, no entanto, perder o foco fenomenológico, a professora Magda Eugénia Pinheiro Brandão da Costa Carvalho Teixeira convida o leitor, em seu artigo "Indecisão plena de promessas: imagens da vida e da infância em Henri Bergson”, a cruzar a imagem da vida como infância com a imagem da infância como vida com o objetivo de repensar o que nos habita como constitutivamente outro: a criança que fomos e a natureza que somos. O viés desta descoberta educativa também está presente no artigo "O terceiro-instruído: Ontofenomenologia e educação em Michel Serres", escrito pela professora Romana Isabel Brázio Valente Pinho. Neste artigo, a professora apresenta um estudo acerca da relevância do pensamento ontofenomênico, epistemológico e educacional de Michel Serres para a implementação das categorias filosóficas: contrato natural e terceira-instrução.

$\mathrm{Na}$ seção Artigos, o professor Amon Pinho apresenta, em "Agostinho da Silva, de engajado filólogo a humanista militante e crítico: itinerário seareiro em tempos de formação do Salazarismo (1928-1933)", um estudo sobre o itinerário teórico-político de Agostinho da Silva entre os anos de 1928 e 1933, focalizando a análise de uma série de artigos publicados na revista portuguesa Seara Nova. A temática do desamparo, em diálogo com a condição humana, se coloca no artigo "A condição humana e a condição docente: das ilusões de onipotência ao reconhecimento do desamparo", do professor Diogo Bogeia. Ao problematizar as subjetividades do ser, o professor discute a condição docente no cotidiano. Ainda considerando o lastro da subjetividade, o pesquisador Pedro Falcão Pricladnitzky amplia a compreensão acerca da obra Recherche de la Verité de Nicolas Malebranche, com especial destaque para a doutrina da visão em Deus. A aceitação das diferenças como próprias da espécie humana para a (re)invenção de nossa educação e sociedade é abordada pela professora Silvia Ester Orrú a partir dos entre- 
lugares da descolonização de nosso ser. Em "A diferença como valor humano: ensaio sobre as contribuições do pensamento de Boaventura Sousa Santos, Gilles Deleuze e Homi Bhabha para o paradigma da inclusão", Orrú trabalha a perspectiva dos autores na abordagem da diferença como valor humano no contexto de construção de uma sociedade inclusiva. Em seguida, o professor Davi da Costa Almeida defende, no artigo "Educação e filosofia para além dos processos de domesticação e de bestialização dos indivíduos", que a filosofia se coloca como uma forma crítica de pensar, capaz de auxiliar na construção de processos educativos que se distanciem dos processos de domesticação e de bestialização dos indivíduos. No artigo intitulado "O embate do encontro", os pesquisadores Fidel Machado de Castro e Silva e Mário Luiz Ferrari Nunes partem de duas divindades gregas - Dionísio e Apolo - para discutir o Currículo Cultural da Educação Física. Para eles, o amparo metodológico na criação filosófico conceitual pode redesenhar relações estabelecidas e permitir jogar com elementos distintos e, inicialmente, não aproximáveis. Na sequência, as pesquisadoras Marli Teresinha Silva da Silveira e Raísla Girardi Rodrigues, bem como o professor Angelo Vitorio Cenci, promovem uma aproximação entre a psicologia social de Mead e a noção de interioridade desdobrada em Heidegger no artigo "Entre Mead e Heidegger: a interioridade desdobrada e a formação humana". No artigo seguinte, intitulado "Materialismo dialético, luta de classes e insights filosóficos sobre a educação a partir de Slavoj Žižek, o professor Hildemar Luiz Rech e o pesquisador Fernando Facó de Assis Fonseca desenvolvem uma importante reflexão acerca da ideia de luta de classes no que se convencionou chamar de era pós-ideológica. No entanto, ao retomarem o pensamento de Žižek, os autores focalizam o conceito de materialismo dialético para demonstrar a contradição interna ao campo ideológico de nossa sociedade. Nesta reflexão, a ideia de educação é apresentada a partir da contradição que mobiliza justamente esta luta de classes. Em "Movimento dos secundaristas brasileiros e o momento sofístico: uma nova história começa a ser contada", a professora Tatiane da Silva e o professor Nathan Crick defendem que o movimento em questão pode ser 
considerado também um momento sofístico tal qual aquele ocorrido no século de Péricles. Para os autores, o momento sofístico corresponde, de acordo com Arendt, ao instante no qual a intersecção entre os termos riqueza, liberdade e poder possibilita aos indivíduos se engajarem na esfera política permitindo assim que influenciem na tomada de decisões. O artigo demonstra que as ações do movimento secundarista evidenciaram o peso da comunicação demandando assim uma educação retórica, a qual inclui não só a formação na palavra em seu sentido dialógico e persuasivo, mas também raciocínio e deliberação. Evidenciado a discussão a partir do prisma do conceito de linguagem unidimensional em Marcuse, a pesquisadora Vivian Baroni defende, no artigo intitulado "A unidimensionalização da linguagem e a fragilização teórica do campo investigativo educacional: desafios para a pesquisa em educação", a importância da retomada dos estudos de caráter teórico, assim como do trabalho adequado do conceito e dos universais, como instrumentos conceituais imprescindíveis na pesquisa que deseja considerar toda a complexidade do campo da educação.

Encerrando esta edição da Educação e Filosofia, a professora Adriana Teixeira Bastos e o professor Cláudio César Torquato Rocha abordam, em "Zaratustra e o Fracasso Pedagógico", o desenvolvimento profissional docente (DPD) a partir da professoralidade, profissionalização e profissionalismo. A investigação conduzida pelos professores evidenciou que o DPD, na atualidade, perpassa questões que evidenciam as diferentes categorias, mesmo que em intensidades distintas. De acordo com os autores, profissionalidade e professoralidade são as categorias que mais dizem respeito a uma estreita vinculação com o desenvolvimento profissional docente por se relacionarem de forma imbricada sem que se possa separar um do outro, ao passo que no profissionalismo e na profissionalização não existe uma relação de complementariedade ou espontânea, mas sem dúvida ambos os lados da relação podem se beneficiar um do outro.

Desejamos a todos que os artigos possam suscitar novas reflexões e ampliar os horizontes! 